\title{
Measuring disparities in access to water based on the normative content of the human right
}

\section{O. Flores Baquero}

Research Group on Cooperation and Human Development (GRECDH) / University Research Institute for Sustainability Science and Technology (IS.UPC), Universitat Politècnica de Catalunya, Barcelona-Tech (UPC)

Institut de Sostenibilitat. Edifici Vértex, Planta 1. Plaça Eusebi Güell, 6. 08034 Barcelona (Spain)

A. Jiménez Fdez. de Palencia

Stockholm International Water Institute, Drottninggatan 33. 11151 Stockholm, Sweden

\section{A. Pérez Foguet}

Research Group on Cooperation and Human Development (GRECDH) / Department of Applied Mathematics III, Universitat Politècnica de Catalunya, Barcelona (UPC), Spain

Department of Applied Mathematics III. Edifici C2 (ETECCPB), 210B. Jordi Girona 1-3, 08034 Barcelona (Spain)

Email: agusti.perez@upc.edu / tel.+34 934011072 / Fax: +34 934054201

\begin{abstract}
Measuring access to water in a post-2015 era involves taking into account the human rights framework. Therefore, its content should be considered to conceptualize the level of service through adequate indicators and to follow-up inequities reduction at global, national and local level. This research develops and tests a methodology to measure intra-community disparities based on human right to water normative criteria through a stratified sampling, splitting households served by community based organizations and those selfprovided. This approach implies considering much reduced populations, thus special care needs to be taken with sample sizes and uncertainty of estimators. The proposed methodology is practical to locate and accurately characterize minority sectors within rural communities and allows moving beyond centraltendency estimators. It implies higher costs for field data collection than traditional approaches, but nevertheless, the over-investment can be assumed economically feasible and extremely relevant from a human rights perspective taking into account the imperative need to have adequate tools for equity-oriented policy making at local level. The research point out how results might be used to shape decision-making processes.
\end{abstract}

\section{Keywords}

Access to basic services, disparities, exclusion, human right to water, Post-2015, sampling 


\section{Introduction and purpose}

There is some international consensus on the need to advance the measurement of access to water at local, national and global level (Cotton and Bartram 2008; Jiménez and Pérez-Foguet 2008; Joint Monitoring Programme 2011). The United Nations Children's Fund (UNICEF) / World Health Organization (WHO) Joint Monitoring Programme (JMP) is based on a technological approach that distinguish between improved or unimproved water sources to measure access (Joint Monitoring Programme 2006). According to this methodology many Latin American countries show quite acceptable basic indicators of access to water (Joint Monitoring Programme 2014a). However, those need to be useful to support policy and decision making for countries with relative high levels of access too; this requires indicators which can capture improvements in the different dimensions of service level. There are some notable initiatives that have shown the need to expand the conceptual framework used to follow up on these issues at different levels (O. Flores et al. 2013; Giné Garriga and Pérez Foguet 2013; Jemmali and Sullivan 2014; Jiménez and Pérez-Foguet 2010; Majuru et al. 2012; Pérez-Foguet and Giné 2011).

The declarations of the United Nations General Assembly (United Nations 2010a) and the Human Rights Council (United Nations 2010b) recognize the human right to water. Despite critiques of the concept (K. Bakker 2007; Parmar 2008) other authors (Mirosa and Harris 2011) conclude that this human right maintains importance as a strategy in the contemporary moment and thus, can be seen as an opportunity to advance in monitoring the sector (O. Flores et al. 2013; Luh et al. 2013). On the one hand, its normative content requires paying attention to some dimensions not always considered in the Water Sanitation and Hygiene (WASH) sector e.g., affordability, some elements of physical accessibility or acceptability. On the other, one of the main contributions of a human rights based approach is the necessity to integrate new methodologies to measure and better understand disparities, id est the situation of the underserved, the most disadvantaged, and vulnerable groups in terms of rights in each context, which requires looking beyond central tendency estimators (United Nations 2012). The necessity to adequately include equity measures is particularly relevant according to WASH issues (Melamed 2012; United Nations 2012) but also considering the rest of development goals (Camfield et al. 2013; Unterhalter and Dorward 2013). Despite the progress made in incorporating the human right to water normative content and methodologies to particularly evaluate disparities reduction within JMP post 2015 proposal at global level (Joint Monitoring Programme 2014b), there are still some elements that remain unsolved if the fulfilment of the human right to water and sanitation is considered in its broad spectrum (Oscar Flores et al. 2014b). Incorporating these elements in monitoring is a complex task which requires political will that does not always exist (United Nations 2012).

A large body of literature has somehow examined and tested methodologies to measure socioeconomic disparities at district or regional level (Arief 1982; D'sa 1986; Haq and Ali 2013; Ohlan 2013). However, there are no specific studies that deal with measuring intra-community disparities considering the human right to water content. This implies defining new indicators and designing methodologies for field data collection.

This research sets out to address this challenge by developing and testing a methodology to measure access to basic water services from a human rights perspective in rural contexts where it is usual to find communitycontrolled water supply systems. In those situations service provision is delegated to community-based organizations (CBOs) but these non-State service providers face some important shortcomings according to the human right to water obligations: i) they cannot solve all water-supply related issues by themselves (Karen Bakker 2008) and thus cannot always guarantee sufficient service levels. Moreover, ii) there is usually an amount of families by no means negligible that for various reasons are not served by them which can be related to some kind of intra-community discrimination (Agrawal and Gupta 2005; Cleaver 2005) and inequitable power relations within communities (McCarthy 2005; Mehta 2001). Taking this into account, the research focuses on those who have been discriminated against by not receiving a drinking-water service. Self-supply solutions emerge in these situations, issue that has recently been a subject of study as an alternative service delivery model (Butterworth et al. 2013; Smits and Sutton 2012).

The proposal includes a field data collection methodology and a set of questions to measure service level based on the human right to water normative framework. Statistically, a stratified sampling, splitting households served by community based organizations and those self-provided, is proposed. This approach implies considering reduced populations and samples, thus special care needs to be taken with sample sizes and uncertainty of estimators. Despite this small analytical effort, results offer a new practical approach to measure the situation of rural water services at community level. This work is not focused on investigating 
about inequality and discrimination causes. It is also necessary to know more about them to propose remedial actions as it is proposed elsewhere (Flores et al., 2014a).

The proposal has been tested in a case study; explicitly, a municipality in northern Nicaragua. It is a good example of a rural context in the region, marked by moderate/high coverage to improved drinking-water sources (Joint Monitoring Programme 2014a), where decentralization of responsibilities to local government authorities with respect to water issues has not been accompanied by effective resources (Novo and Garrido 2014). More details follow in next subsection. Then, the methodology proposed is explained, and some illustrative results are used to discuss the benefits and limits of the proposal.

\section{Case study}

The human right to water is explicitly mentioned in latest national Water Law (Government of Nicaragua 2007) and Nicaraguan State has committed itself to formally delegate service provision in rural areas to endusers' committees of drinking water and sanitation (CAPS) (Government of Nicaragua 2010). It is common to find drinking water systems managed by CAPS that provide the service to the population of rural communities in the country. Different studies show shortages in the service delivered (CODA 2011; O. Flores et al. 2013; Rob ES Bain et al. 2012; World Health Organization and UNICEF 2010) and intra-community disparities (Oscar Flores et al. 2014a)

San Sebastian de Yalí (SSY) municipality within Jinotega department is located in the central north region of Nicaragua (figure 1). The Municipal Water and Sanitation Unit (UMAS) is the responsible of water and sanitation rural services. It is manned by two specialists that have to cover 22500 people located in 74 disperse rural communities, covering an area of $402 \mathrm{~km}^{2}$. According to municipal data there are 67 CAPS of which 15 are legally registered according to the new Water and Sanitation Committees Law (Government of Nicaragua 2010). Based on municipal data, water access and sanitation coverage in the area was about 70 and $80 \%$ respectively in 2012 .

Figure 1: Location of the case study
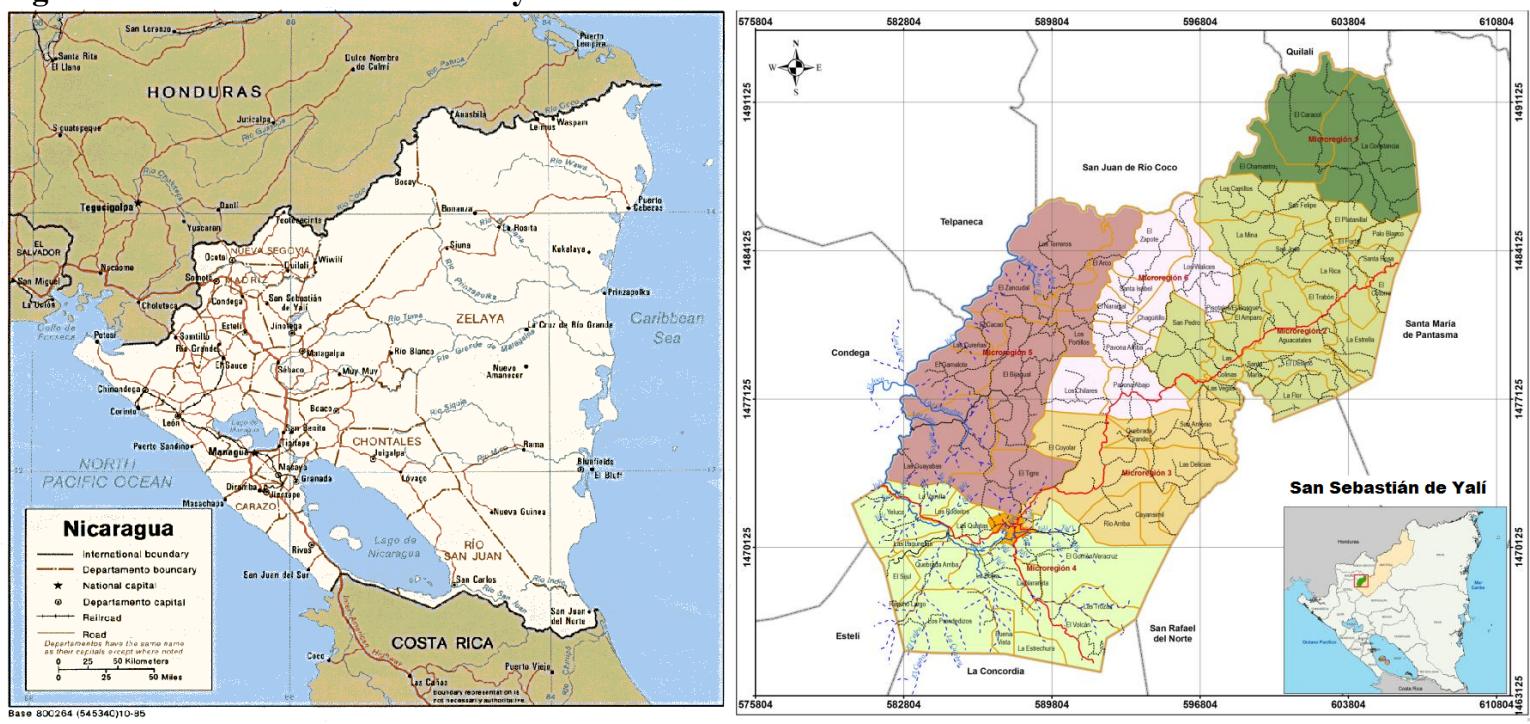

As it was mentioned before, the study focuses on conceptual and methodological issues to measure disparities in access to water. A detailed description of the overall results for SSY municipality, including precision, is out of the scope of the paper. Thus, despite data were collected in all 74 communities of SSY municipality, results presented herein focus on a case study of five communities with 296 households (154 served by CAPS and 149 not served by CAPS). Communities have been selected representing different scenarios in the municipality. Table 1 describes the existence and basic characteristics of water supply systems and the type of drinking water sources in those cases of self-provision, in each of these five communities used to test the methodology. In this municipality there are no pumped systems and according to the infrastructure they mainly differ on the type of distribution scheme and the existence of chlorination systems in operation. 
Table 1. Basic characteristics of community managed water system and self-provision drinking water sources

\begin{tabular}{|c|c|c|c|c|}
\hline \multirow{2}{*}{ Community } & & \multicolumn{2}{|c|}{$\begin{array}{l}\text { CAPS as service provider (basic } \\
\text { characteristics of systems) }\end{array}$} & \multirow{2}{*}{$\begin{array}{l}\text { Self-provision } \\
\text { (drinking water } \\
\text { sources) }\end{array}$} \\
\hline & $\begin{array}{c}\text { Category } \\
\text { (technology) }\end{array}$ & $\begin{array}{c}\text { Chlorination } \\
\text { systems working }\end{array}$ & Type of connection & \\
\hline A & $\begin{array}{l}\text { Gravity fed } \\
\text { (2 systems) }\end{array}$ & $\begin{array}{l}\text { System 1: Yes } \\
\text { System 2: No }\end{array}$ & $\begin{array}{l}\text { Piped water into dwelling // } \\
\text { yard }\end{array}$ & $\begin{array}{l}\text { Surface water and } \\
\text { unprotected springs }\end{array}$ \\
\hline B & Gravity fed & No & Public tap/standpipe & $\begin{array}{l}\text { Surface water, protected } \\
\text { and unprotected springs }\end{array}$ \\
\hline $\mathrm{C}$ & Gravity fed & No & Public tap/standpipe & $\begin{array}{l}\text { Protected and } \\
\text { unprotected springs. } \\
\text { Protected dug-wells }\end{array}$ \\
\hline $\mathrm{D}$ & \multicolumn{3}{|c|}{ Without system } & $\begin{array}{l}\text { Surface water, protected } \\
\text { and unprotected springs }\end{array}$ \\
\hline $\mathrm{E}$ & Gravity fed & Yes & $\begin{array}{l}\text { Piped water into dwelling // } \\
\text { yard }\end{array}$ & $\begin{array}{l}\text { Unprotected springs and } \\
\text { piped systems indirectly } \\
\text { through a neighbour }\end{array}$ \\
\hline
\end{tabular}

Table 2. Main steps of the methodology

1 UMAS convenes a meeting with community leaders

\begin{tabular}{|c|c|c|c|}
\hline \multirow{4}{*}{ 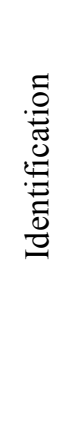 } & 2 & $\begin{array}{l}\text { Survey team generates a census of the households from community distinguishing two } \\
\text { subgroups depending on the type of water service provider: i. Non-State Community } \\
\text { Based Organizations, ii. Self-provision (informal) }\end{array}$ & \\
\hline & 3 & $\begin{array}{l}\text { Supervisor determines the required sample size to produce estimates with sufficient } \\
\text { precision for local level decision-making for the two subgroups }\end{array}$ & Table 4 \\
\hline & 4 & $\begin{array}{l}\text { Survey team randomly selects households to be surveyed for the two subgroups using } \\
\text { the census }\end{array}$ & \\
\hline & 5 & $\begin{array}{l}\text { Survey team in collaboration with community leaders define community maps and the } \\
\text { most natural/shortest routes to visit households selected }\end{array}$ & \\
\hline \multirow{3}{*}{ 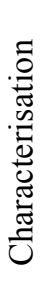 } & 6 & $\begin{array}{l}\text { Service level is evaluated in all households selected regardless of the type of service } \\
\text { provision scheme }\end{array}$ & \\
\hline & 7 & Supervisor validates surveys in the field & \\
\hline & 8 & $\begin{array}{l}\text { Exploiting data: Indicators and indices construction and analysis of intra-community } \\
\text { disparities }\end{array}$ & Table 3 \\
\hline
\end{tabular}




\section{Research design and methodology}

The background to this research lies in the comments of the UN Special Rapporteur on the Human Right to Drinking Water and Sanitation when it is considered that i) in order to endure non-discrimination, there is a need to look beyond aggregated outcomes and identify disparate impacts or less favourable treatment over time and ii) that for small groups, special studies are needed, as their situation cannot be measured through the standard survey design used by global monitoring systems (United Nations 2012). To tackle the matter, the approach proposes two relevant innovations when a rural household survey is conducted: a) a methodology to identify families not currently served by communitarian service providers and $b$ ) a simple set of questions to characterise the level of service based on the human right to water normative criteria. The methodology designed is presented in table 2 and described in detail in this section.

\section{A method to identify reduced populations within rural communities}

The first five steps of the eight-step methodology are described in this section. First of all, technicians from the UMAS called community leaders and members of the CAPS board to a meeting. It is an essential starting point as it is the time when people in communities are informed about the work and get involved in helping the team in the logistics of the data collection. Bennett et al (1991) consider that the selection of households to be polled based on an exhaustive census of the households from community is the best option to ensure randomness when choosing the sample. The methodology takes up the idea for the second step and proposes to distinguish two subgroups of households in each community where one subgroup is made up of those families who are not served by any water system managed by a CAPS. The other subgroup is made up of those who are in the opposite situation. This separation is useful to find and characterize those small discriminated groups not served by communitarian systems while ensuring a greater representativeness.

Thirdly, the sample size is estimated in situ based on the real population of both subsets. The sample size is fixed as the smallest integer verifying that the maximum confidence interval of the estimate is less than an admissible error, e. Different type of indicators, and thus of estimators, are involved (see Table 3). An approximation to the interval length based on the normal distribution is the usual option (Cochran 1973, third edition). As the household sampling is without replacement, if populations that are not large, the interval is corrected for finite populations.

However, sample size determination with very reduced populations - as it is the case of communities studied or with estimates far from being normally distributed cannot be based on this approximation, and sample size has to be computed from exact confidence limits. Here, the sample size is determined for proportions, in agreement with majority of cases in Table 3. The Clooper-Pearson interval (Reiczigel 2003) corrected for finite populations (Anderson and Burstein 1967, 1968; Burstein 1975) is used.

The sample sizes are given by a formula that implicitly determines those for a given precision, confidence level and population sizes. Precision and confidence level are fixed as a compromise between accuracy and financial and time costs. The approach produces estimates with low precision but sufficient for distinguishing extreme behaviours, and therefore for supporting basic local level decision-making. User-friendly tables were designed to facilitate its implementation in the field.

Fourthly, specific households to be surveyed are randomly selected through simple techniques making use of both censuses and the sample size defined in previous steps. Then, community maps were generated in collaboration with community leaders to facilitate the organization of field data collection.

\section{A method to characterise the level of service based on the human right to water normative criteria}

Special attention was paid to the idea of measuring access to water based on service level concept while considering the human right normative content (availability, physical accessibility, affordability, acceptability, and quality). For that purpose a combination of different sources of information has been considered as Giné-Garriga et al (2013) proposed. Relatively simple and precise questions were included in household surveys that would enable to build a set of indicators to cover the first four dimensions. Additionally, an audit at the water points and/or systems was carried out to evaluate water quality/safety criteria, specifically to determine presence of faecal coliforms. Ministry of Health staff (SSY) coordinated the analysis of samples. Available data from surveys were validated in two different ways: First, the supervisor looked through surveys for mistakes in the field. Then, different cross-questions let us identify possible inconsistencies when data are transfer into the database built for their analysis. 
Finally, a set of indicators was defined in order to measure the different human rights dimensions. In cases where there is more than one indicator for each criterion, the information is added in a single simple index relative to each of the criteria. It is not the intention of this article to going deeper about the methodology for construction of composite indicators as a unique index is not proposed herein. Moreover, indicators considered are based on Flores et al (2013) work where the most relevant decisions about indicators and index construction are argued. These are summarized in table 3, which identifies those indicators that have been enhanced for this case study. All indicators take values between 0 and 1, indicating the poorest level and the optimum conditions, respectively. In order to aggregate indicators into subindices, two different approaches were considered: when indicators can compensate each other's performance, and the contrary. Additive aggregation has been used for the former and multiplicative aggregation for the later as it is suggested in different works (Garriga and Foguet 2010; Munda and Nardo 2005; Nardo et al. 2005; Saisana et al. 2002). Uncertainty and sensitivity analysis proposed elsewhere (Saisana et al. 2005) for the quality assessment of composite indicators are beyond the scope of this article.

\section{Results and discussion}

Contributions in this section have been grouped in four blocks. First of all, the results of applying the method to identify reduced populations within rural communities are presented. Then, intra-community disparities among the two sub-groups defined and using specific metrics based on the human right to water normative content are presented. Thirdly, a basic economical assessment related to the overall field data collection process is included to highlight the feasibility of the proposal. Finally, it is shown how results might be used to shape decision-making processes.

Table 3. Indicators considered (O. Flores et al. 2013). Improvements based on *Rietveld et al (2009) **Jiménez and Pérez-Foguet (2012).

\begin{tabular}{|c|c|c|c|c|}
\hline \multirow{2}{*}{$\begin{array}{l}\text { Normative } \\
\text { criteria }\end{array}$} & \multirow{2}{*}{ Elements // indicators } & \multirow{2}{*}{$\begin{array}{l}\text { Type of variable } \\
\text { (indicator) }\end{array}$} & \multicolumn{2}{|c|}{$\begin{array}{c}\text { Scoring } \\
\text { (limit values) }\end{array}$} \\
\hline & & & $\mathbf{0}$ & 1 \\
\hline \multirow{4}{*}{ Availability } & Sufficient quantity & $\begin{array}{l}\text { Ordinal } \\
\text { (5 levels) }\end{array}$ & $<5 \mathrm{lpd}$ & $>100 \mathrm{lpd}$ \\
\hline & Sufficient quantity (perception) & $\begin{array}{l}\text { Ordinal } \\
\text { (3 levels) }\end{array}$ & $\begin{array}{l}\text { Not enough for } \\
\text { drinking }\end{array}$ & $\begin{array}{c}\text { Enough for all } \\
\text { domestic purposes }\end{array}$ \\
\hline & Continuity* & Continuous & $\begin{array}{l}0 \text { hours/day \& } 0 \\
\text { days/month }\end{array}$ & $\begin{array}{c}24 \text { hours/day \& } 30 \\
\text { days/month }\end{array}$ \\
\hline & Reliability & Binary & $\begin{array}{l}\text { Sometimes they have } \\
\text { to use other sources }\end{array}$ & All year round \\
\hline \multirow{2}{*}{$\begin{array}{c}\text { Physical } \\
\text { Accessibility }\end{array}$} & Proximity (time spent) & $\begin{array}{l}\text { Ordinal } \\
\text { (4 levels) }\end{array}$ & $>30$ minutes & $\begin{array}{l}\text { Piped into house / } \\
\text { compound }\end{array}$ \\
\hline & Security (in paths) & Binary & No & Yes \\
\hline $\begin{array}{l}\text { Quality and } \\
\text { safety }\end{array}$ & Faecal coliforms** & $\begin{array}{l}\text { Ordinal } \\
\text { (3 levels) }\end{array}$ & $>10 \mathrm{CFU} / 100 \mathrm{ml}$ & $0 \mathrm{CFU} / 100 \mathrm{ml}$ \\
\hline Affordability & Affordability (perception) & Binary & Too expensive & Fair \\
\hline Acceptability & $\begin{array}{l}\text { Organoleptic properties } \\
\text { (perception) }\end{array}$ & Binary & $\begin{array}{c}\text { Bad colour, odour or } \\
\text { flavour }\end{array}$ & $\begin{array}{l}\text { Good colour, odour } \\
\text { and flavour }\end{array}$ \\
\hline
\end{tabular}




\section{Sample size implications to identify reduced populations}

The decision on the size of a sample is critical as it affects the cost and the precision of the survey (Bennett et al. 1991; United Nations Children's Fund 2006). The common approach is based on the approximation to the normal distribution where the confidence level and required precision are the main design factors for sample size estimation (United Nations Children's Fund 2006). Nevertheless, population size is too small when it is necessary to produce precise estimates for rural communities. Thus, as it was mentioned before, a different approach based on exact confidence limits of binomial distribution, corrected for finite populations is applied to resolve this problem.

Table 4 summarizes information on the size of the community (I), a comparative of two possible statistical samplings taken into account the methodological approach proposed (II and IV) and the sample design finally adopted (III). When the approach is used assuming low precision and without stratification, results are shown in column IV. These numbers can be used to obtain average numbers of the indicators for policy making at community level. However, if a clear picture of disparities among subgroups is sought, a stratified sample is required and therefor, proposed herein. In this case, population size is reduced but the sample size can be designed considering the same approach. A border case when the population is too reduced is shown for community E where 7 families composed the "self-provision" subgroup.

During field work, it is often difficult to reach the sample design in the case of self-provision subgroup when the number of households is much reduced -explicitly below 10- as it is shown in column III. Total numbers have been almost achieved but not exactly the disaggregated ones. Main reasons are: i) serious difficulties in reaching some of these families due to their location in inaccessible areas, combined with ii) very few options for substitution of families with other belonging to the same subgroup (due to reduced numbers) when there were no adults at home in the moment of home visit. Consequently, results for these concrete subgroups at community level should be carefully analysed for policy making and for comparison with other communities purposes. Recall that $\mathrm{d}$ for figures corresponding to the overall sample are $\mathrm{e}=0.110 .13$ with a 0.9 . Therefore, more precise results are obtained when aggregated comparisons are considered. 
Table 3. Design of sample size based on the size of the community and actual polled sample. $(\alpha=0.9 ; \mathbf{e}<0.2$. Except $*$ where $\alpha=0.8 ; \mathbf{e}<0.25)$.

\begin{tabular}{|c|c|c|c|c|c|c|c|c|c|c|}
\hline \multirow{2}{*}{ Community } & \multicolumn{3}{|c|}{ I. Number of Households } & \multicolumn{3}{|c|}{$\begin{array}{l}\text { II. Number of Households } \\
\text { (sample design - stratified) }\end{array}$} & \multicolumn{3}{|c|}{$\begin{array}{l}\text { III. Polled Households } \\
\text {-stratified- }\end{array}$} & \multirow{2}{*}{$\begin{array}{c}\text { IV. Number of } \\
\text { households } \\
\text { (sample design - no } \\
\text { stratified) }\end{array}$} \\
\hline & Self-provision & $\begin{array}{c}\text { CAPS } \\
\text { (service } \\
\text { provider) }\end{array}$ & TOTAL & Self-provision & $\begin{array}{c}\text { CAPS } \\
\text { (service } \\
\text { provider) }\end{array}$ & TOTAL & Self-provision & $\begin{array}{c}\text { CAPS } \\
\text { (service } \\
\text { provider) }\end{array}$ & TOTAL & \\
\hline A & 9 & 38 & 47 & 7 & 14 & 20 & 4 & 15 & 19 & 15 \\
\hline $\mathrm{B}$ & 15 & 32 & 47 & 10 & 13 & 23 & 11 & 14 & 25 & 15 \\
\hline $\mathrm{C}$ & 73 & 40 & 113 & 17 & 14 & 30 & 14 & 15 & 29 & 17 \\
\hline $\mathrm{D}$ & 38 & 0 & 38 & 14 & 0 & 14 & 14 & 0 & 14 & 14 \\
\hline $\mathrm{E}$ & 7 & 44 & 51 & $5^{*}$ & 14 & 19 & 2 & 18 & 20 & 15 \\
\hline TOTAL & 142 & 154 & 296 & 48 & 55 & 106 & 45 & 62 & 107 & 76 \\
\hline
\end{tabular}




\section{Showing intra-community disparities based on the human right to water normative content.}

This research has incorporated new dimensions to measure access to water based on human rights criteria, which provide more information than current technology-based approaches. If we focus on the indicator "access to drinking water" considered in Joint Monitoring Programme, all households using communitycontrolled water supply systems have access to an improved water source and the majority of families based on self-provision will be considered as using unimproved drinking water in this case study. However, a more nuanced picture emerges when analysing separately all five criteria described in table 3 . Figure 2 presents an average across all five communities sampled that can be understood as an overall value of each human right to water criteria differentiating between people served and not served by CAPS.

Availability and quality are the main shortcomings in communities studied while it seems that physical accessibility is by and large adequate. The low value for availability is mainly due to the poor continuity and seasonality of the supply. It is common that households express the existence of moments during the year when they need to use alternative sources for drinking water. As observed during field data collection, traditional sources are the common alternative sources used in communities when community-based supply systems fail. Moreover continuity of the service is usually lower than 24 hours in a day and only some days during the week. Systems managed by CAPS often suffer breakdowns, cuts of water and flow problems in some water points. Finally, some families mentioned that available water is just enough for drinking water purposes. These problems explain low values in availability dimension.

Quality criterion is an issue of concern as most of the water supplies examined were contaminated with faecal coliforms which is in line with results from the Rapid Assessment of Drinking-Water Quality (RADWQ) carried out in the country (World Health Organization and UNICEF 2010). Less than 1 out of 5 families were drinking water free from faecal coliforms at the moment of water points and systems auditing. For those families self-provided, about $64 \%$ are using drinking water sources with more than $10 \mathrm{cfu}, 20 \%$ between 10 and 0 cfu and just about $16 \%$ free from coliforms. When analysing households that depend on systems managed by CAPS, the distribution of results is $0 \%, 82 \%$ and $18 \%$ respectively. It can be realized that unacceptably high contamination ( $>10 \mathrm{cfu}$ ) is more severe for those self-provided. However, the proportion of families which are drinking water free from coliforms is similar in both subgroups, highlighting that rural service providers -and therefore duty-bearers (United Nations 2010a)- also have problems to ensure safety criterion to the users of community drinking water systems (right-holders).

The dimensions related to affordability and acceptability score considerably high. The water supplies were found to be affordable and acceptable, as per the indicators and criteria used. Flores et al., (2013) discuss the difficulties of measuring access to water based on human right to water criteria at local level. The "standard" indicator for affordability (percentage of household expenditure on drinking water), is not simple to measure. Its meaning and standards have not been precisely defined yet. Income is hard to measure because polled families usually don't know or are reluctant to give information about it. Even more, income is very variable throughout the year. For that reason we opted to use a perception indicator as a proxy of affordability criterion. While being more practical, its subjectivity is an important limitation. It should be noted that for households that are not connected to the system (or those connected but not paying any tariff), affordability scoring is maximum as it is assumed that these families can afford the water they used. On the one hand, this fact can be considered in itself a financial advantage as compared to those families which depend on a service provider that has to be remunerated. Moreover, it could be a reason for not wishing to be connected to community-controlled water supply systems. But on the other, paying for repairs is a common practice in selfsupply situations despite economic difficulties with buying spare parts and contracting a local mechanic for repairs usually exist in this contexts (Sutton et al. 2012). Thus, i) it is important to highlight that the indicator used has its own limitations and more work is needed to investigate indicators and methodologies that allow us to assess affordability more precisely. ii) Furthermore, it should be noted that despite not paying any tariff may be scored as maximum according to affordability criterion, it could compromise the sustainability of the service. For these reason, it is important to complement this analysis with a sustainability assessment.

Due to different individuals have different notions of what is acceptable, monitoring acceptability is probably one of the most challenging aspects of monitoring the human rights to water (UN Special Rapporteur on the human right to safe drinking water and sanitation 2014). Moreover, acceptability includes distinctive elements in case of sanitation -privacy, comfort, dignity- (Langford et al. 2014; United Nations 2010b) which do not apply for drinking water. Even more, acceptability criterion is normally associated to organoleptic properties 
which are mainly linked to the quality dimension when specific metrics for the human right to water have been put into practice (O. Flores et al. 2013). Traditionally there has been a current of thinking that argued for the use of protected supplies in place of disinfection (Drown 1894) as there is a human aversion to the use of chlorine, due to its impact on the aesthetic qualities of drinking water (Jacangelo and Trussells 2001). The indicator proposed may be used to identify probable different notions of acceptability between those drinking chlorinated water and those using protected supplies (springs and wells) but field data collection show that chlorination systems are often lacking or not working in most of the communities visited in this region. This evidence can partially explained similar results acceptability criterion.

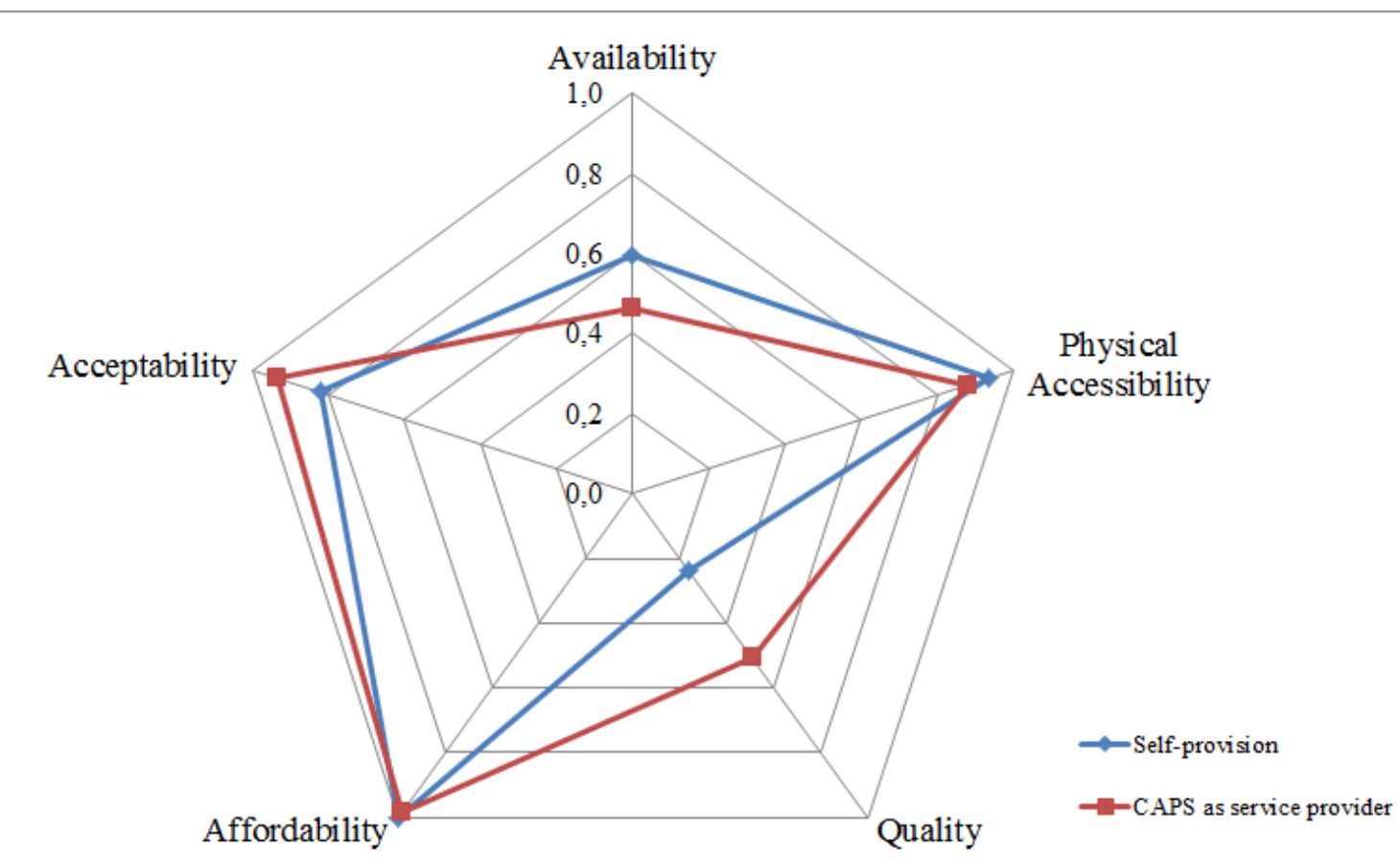

\section{Figure 2. Overall disparities in access to water between families served and not served by CAPS according to human right to water normative criteria. All communities involved}

The Special Rapporteur also notes that "the target may be achieved but access to water as guaranteed by human rights remains unequally enjoyed by many" (United Nations 2012). Taken this idea into account, the research also focuses on those families discriminated or not served by communitarian systems in each community. Figure 3 shows the importance of disaggregating data into the two types of families described before, i.e. those served by the community-controlled water supply systems and those excluded. The spider diagram shows the situation of families in a type of community (A) which represents a frequent example in the region: Those self-provided use surface water and unprotected springs while the other community members are connected to water systems into their dwelling or yard. There are two systems in community A. Most part of the households are provided by the system which belongs to the own community and the others (just some families) are connected to a system from the neighbouring human settlement. Both systems are relatively new and both have chlorinating equipment.

Households based on self-supply have a worse level of water service as regards physical accessibility, quality, and acceptability. According to physical accessibility, whereas the former have to walk to fetch water, the later have their own water point at home or at the compound. Some of those that have to move to distant places even express their insecurity in the paths. The quality of water is different in both systems $(0 \mathrm{cfu}$ in the system from community $\mathrm{A}$ and between 0 and $10 \mathrm{cfu}$ in the neighbouring system wher the chlorinator was not working during the data collection campaign). Due to the presence of coliforms in system 2, quality criterion scores less than 1 for those served by CAPS. However, safety is a most serious problem for those selfprovided as results show. It is evident that families not connected to the system are uncomfortable with the 
type of water they have to drink, as reflected in acceptability criterion. The diagram in Figure 3 clearly shows that the situation of these discriminated families would be "hidden" by the average at community level (as it normally occurs when using central tendency estimators) if the information is not taken, analysed and displayed separately. However, they score well with respect to availability criteria. It is explained due to they can collect water from their own sources (springs, and surface water) all the year and permanently.

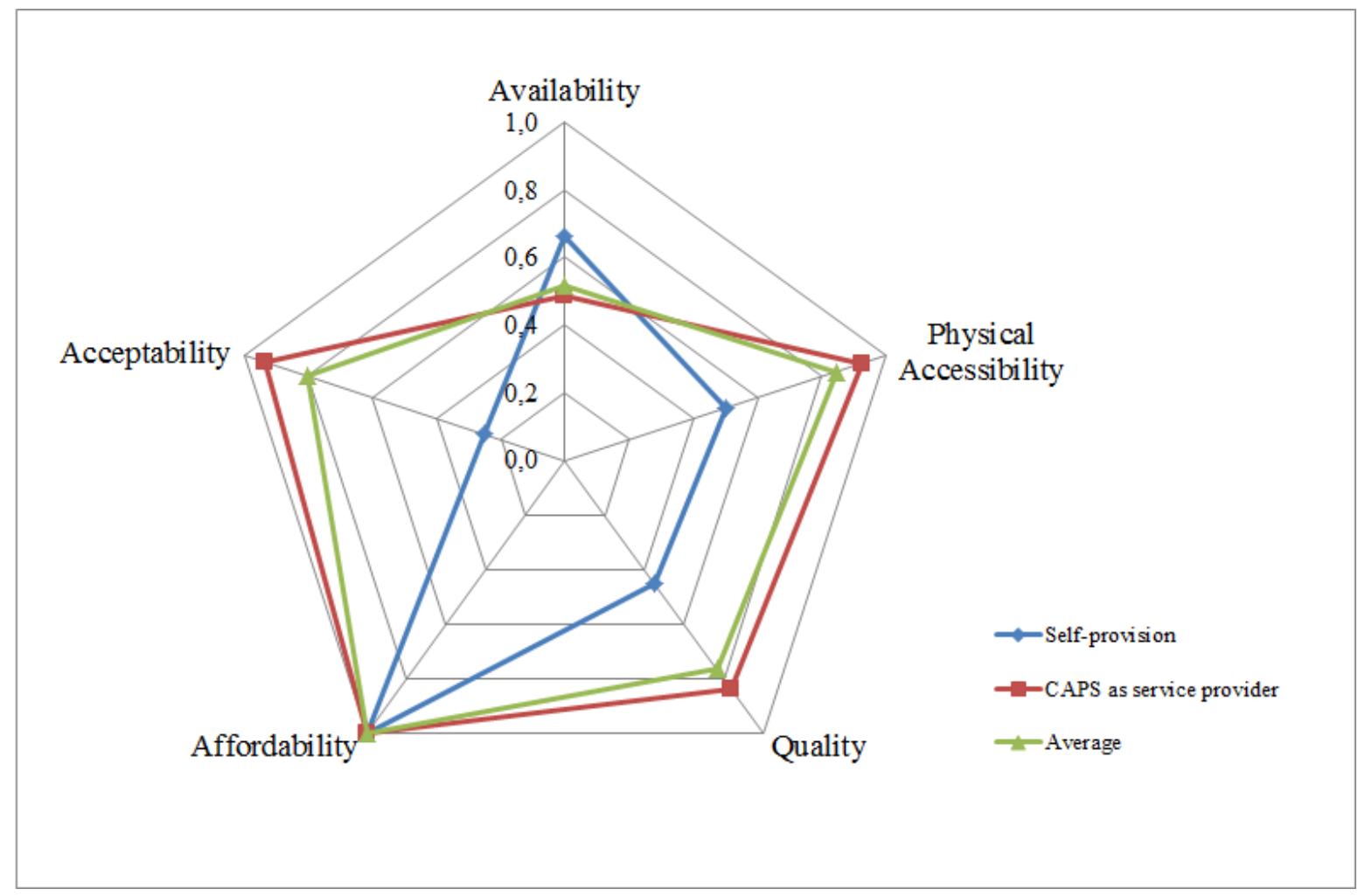

\section{| Figure 43. Comparison between disaggregated and averaged results in Community $\mathrm{A}$}

Finally, this approach allows visualizing another typical situation in the region, exemplified by community B in figure 4. We have already noted (figures 2 and 3 ) that it is common when using this set of indicators that availability may score higher for those not using water systems managed collectively by CAPS. It can be realized that physical accessibility is considerably higher for those who are not provided by CAPS. On the one hand, there are a lot of unprotected springs in this region and most of those not served by communitarian systems own or share their own sources. It is also common that they had constructed simple systems to carry water from springs to their homes through hosepipes. On the other hand, there are a lot of communities in the municipality (such as B or C) where communitarian systems were not constructed on a domiciliary logic, but rather water is distributed by a scheme of public standpipes. The system in this community is over 20 years old (19 years old in the case of C), a period in which most of interventions in the region were based on this type of distribution schemes. It requires that people have to move from their homes to the public fountains. As it was just mentioned, families not served by the system within the community do not have to fetch water because they use artisanal ways to carry water from sources to their houses which explains differences within physical accessibility criterion.

According to water quality, community B example shows better results in water points managed by CAPS than those not served by them. However, faecal coliforms value is found within 0 and $10 \mathrm{cfu}$ and represents a widespread situation in the region where a chlorinator was installed in the system but it is in a state of neglect. 


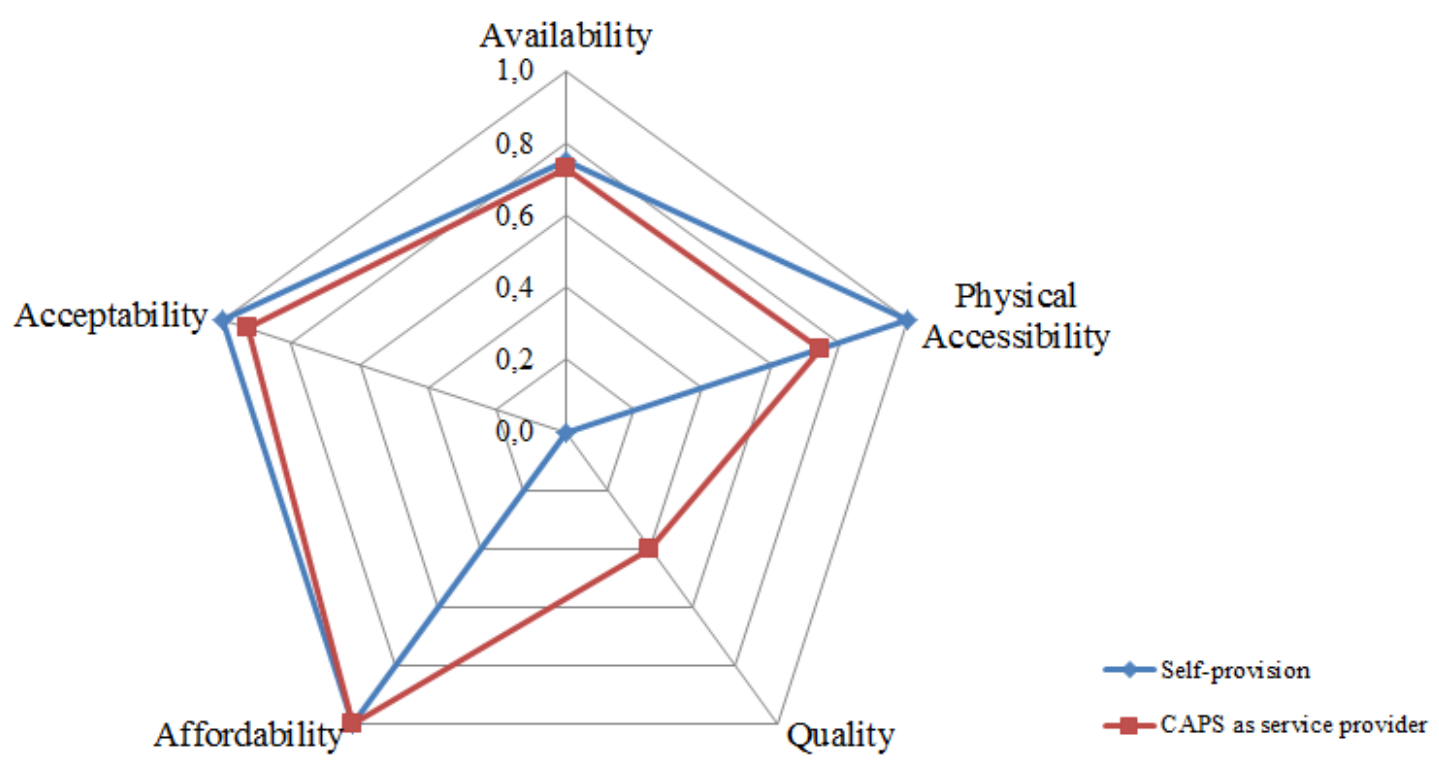

Figure 4. Disparities in access to water as the normative dimensions of DHA between families served and not served by community-controlled water supply systems. Community B

\section{Feasibility of the overall proposal for field data collection}

According to field work implications, 6-7 survey takers, two drivers on average per day, a laboratory technician and a supervisor in a full time job carried out the data collection process in the whole rural municipality which has been executed during 41 days in 2012. Cost for field data collection of the proposed stratified survey was approximately 5700 USD where main costs are enumerators and drivers' salaries and travel expenses, fuel and expenditure on stationery and office supplies. Salaries of the Ministry of health and UMAS staff have not been included as the work carried out by them is part of their routine activities.

Considering a campaign in which just one sample is defined in each community (instead of two subsamples), the sample size (number of households to be polled) will be reduced to 65 per cent but the number of communities to visit is obviously the same. Some repercussions for field data collection design are discussed below where two possible options for field data collection -considering only one sample per community- have been analysed: i) to reduce the number of days necessaries to carry out field work but keeping the number of enumerators constant. In this case, all the communities in the municipality could be monitored in 28 work days instead of 41. ii) To reduce the working team while maintaining the duration of field work. 3-4 enumerators, one driver, a laboratory technician and a supervisor could be able to complete the task in 41 days in this option. These alternatives would mean a reduction in costs about $70-80 \%$ of the proposed stratified survey.

On a separate issue, enumerators and supervision salaries could be higher if the services of an external consultancy are contracted (up to $7500-8000$ USD given Nicaraguan wages), as a combination of voluntary work and university internship of local students was considered for field data collection in our case study. However, it is common to conduct this type of monitoring making effective use of existing local human resources in some rural contexts as it is the case of Nicaraguan municipalities. Furthermore, CAPS and/or community leaders could be involved in updating information in their communities -including both CAPS and no CAPS users' subgroups- which will result in costs reduction. Their participation in monitoring initiatives 
will be also worthwhile as it will help them to identify potential problem areas and consequently stimulate action (Bolt et al. 2001).

SSY Municipality annual investment in WASH activities during 2011 was 60.000 USD. It could be reasonable in terms of costs and appropriateness to plan an updating in a 4 year period to identify and monitor advances and progress in inequalities reduction. It represents less than $2.5 \%$ of annual budget. Elections in the municipalities take place each four years and the first one is when the new local governments define and propose a multi-annual municipal budget that afterwards will be reconsider yearly.

\section{Policy implications}

Human right to water imposes on States parties various type of obligations. A number of general and specific obligations as well as core obligations of immediate effect are identified in GC15 (United Nations 2002) and other documents that the Special Rapporteur has published to clarify the scope and content of the Human Right to Water during her term of office (United Nations 2010a, 2011). Those are used as a starting point for explaining the way in which this research may improve policies to better comply with this emerging human right.

States parties have the obligation to monitor the extent of the realization, or the non-realization, of the right to water and indicators used should address the different components of adequate water (such as availability, safety and acceptability, affordability and physical accessibility). This article presents a proposal to measure the right of access to water and water facilities and services based on these five components. Once those are measured at decentralized level, local authorities could define water strategies and a plan of action to realize this right which should move beyond the construction of new systems. Rehabilitation of existing systems, actions to improve quality of water or management-supporting activities should be promoted. Even more the process of defining the strategy and plan and their content shall give particular attention to disadvantaged groups. The method proposed to identify reduced populations within rural communities can be used to integrate an equity approach throughout the planning process, involving the construction or rehabilitation of systems for unserved families within communities. It requires specific financing and appropriate local capacities.

Progressive realization implies, amongst other things, that States must move beyond minimum standards towards gradually achieving higher levels of service. This would require countries to measure specific human rights indicators and benchmarks periodically and to take positive measures to assist individuals and communities to improve their level of service.

Extending facilities to the last percentage of unserved and hardest families to reach may be too expensive (Butterworth et al. 2013; Smits and Sutton 2012). However, States parties have the obligation to adopt relatively low-cost targeted water programmes to protect vulnerable and marginalized groups. The methodology proposed give pertinent insights about the situation of those families which based their access to water on self-supply mechanisms. To encourage and regulate self-supply in certain contexts is needed in order to reach the goal of universal access.

States parties have the obligation to take measures to prevent, treat and control diseases linked to water. At the same time, it needs to be recognized that traditional sources might be used at some points in rural areas with community-based supply as it is seen when analysing availability criterion. As it is suggested elsewhere (Hunter et al. 2009) health benefits attributed to the consumption of safe water are almost entirely lost if raw water is consumed even once over the course of a few days. A suitable and sustainable way forward in these contexts may be to include traditional water sources (dug wells and springs) as a part of communitarian systems and implement all necessary measures to protect them within verified risk management plans. Capacity development on quality issues might be necessary in order to reduce the capability gap of local authorities that usually exists in these contexts.

To meet their responsibility, service providers should take certain measures, such as ensuring that the water they provide is of safe quality, ensuring the regularity of supply or not discriminating in their operations. However, community based organizations as service providers face some difficulties (due to lack of capacity) to meet their responsibilities as it is reflected in this article. The approach enables regulatory authorities and technical assistance teams to better understand the level of service that CBOs are delivering to citizens taking into account the human rights normative content. Thus, this research might also be used to shape decision- 
making processes in relation to regulation, support and capacity developing to community based service providers.

\section{Conclusions}

Nowadays, measuring access to water at global level determines one "fit to all" indicator, which is excessively simplistic in some settings, and does not show existing inequalities. An approach based on aggregate outcomes and central tendency estimators does not provide any particular incentive to focus and reach marginalized groups. Despite new trends towards global monitoring are emerging in the post-2015 context, shortages mentioned have influenced national monitoring systems too often. The proposed methodology implemented at local level provides some findings to be considered as recommendations for local, national and global monitoring platforms:

The approach is practical to locate those minority sectors within rural communities that often do not benefit from the same services than the others. The sample design serves as a basis for reasonably accurate estimates of the total number of members of each sub-group within the community which is critical to broadly characterise access to water. This is very useful, as indicators can be displayed according to the percentage composition of the community besides the most common average values.

Local level approaches for monitoring rural water supplies as the one proposed could be used to test methodologies that will be part of monitoring systems at supra-local level. Lessons learned at this level may feed national and international information tools when they assimilate human rights framework. At international level, JMP post-2015 proposal is evolving in this sense as it includes a methodology to monitoring inequalities reduction in access. Doing so requires data disaggregation on four dimensions ${ }^{1}$ (Joint Monitoring Programme 2014b) but it is not specify yet the way data will be collected to ensure precise estimates of sub-groups considered. Adaptations of the methodology proposed could resolve the challenge.

Progressive realization of the human right to water requires not staying in a basic service level but to improve it, thus a multidimensional approach as the one presented can be apply to evaluate progress. Moreover, the methodology can be used to deepen into complex and multidimensional realities where data can yield to unexpected results as it is the case of a better position with regard to some criteria of people served by nonpiped systems versus others that are supplied through piped systems as the latter is situated on the top of JMP drinking-water ladder. This is useful when identifying and characterizing communities in order to develop equitable and efficient strategies for resource allocation which is a requisite clearly justified from the perspective of the human right to water.

Finally, the methodology proposed implies higher costs for field data collection than traditional approaches. However, as a result of the research, the over-investment can be assumed economically feasible considering municipal annual budgets, the required frequency for field data collection and specially taking into account the imperative need to have adequate tools for equity-oriented policy making at local level.

In this regard, the article contributes to shape decision-making processes supporting local authorities to define appropriate plans of action which should include equity measures, visualizing the necessity to take steps concerning the protection of traditional water sources, encouraging and formalizing self-supply in certain contexts, regulating the actions of community based service providers and giving pertinent insights to achieve the implicit obligation of States parties to develop the capacity of these non-State service providers.

\footnotetext{
${ }^{1}$ Rich and poor, urban and rural, slums and formal urban settlements and disadvantaged groups -which encompasses prohibited grounds of discrimination such as gender, ethnicity, race, colour, religion, caste, national or social origin- and the general population
} 


\section{Acknowledgements}

The authors would like to thank ONGAWA-Engineering for Human Development and the Centre for Cooperation and Development (CCD) of the Universitat Politècnica de Catalunya (UPC) for supporting this research. Moreover, authors would like to express their gratitude to technical staff from San Sebastián de Yalí Municipality and Ministry of Health (Minsa) and students from Universidad Nacional Autónoma de Nicaragua (UNAN-León) for their valuable contribution during field work.

\section{References}

Agrawal, A., \& Gupta, K. (2005). Decentralization and participation: The governance of common pool resources in Nepal's Terai. World Development, 33(7), 1101-1114, doi:10.1016/j.worlddev.2005.04.009.

Anderson, T. W., \& Burstein, H. (1967). Approximating the Upper Binomial Confidence Limit. Journal of the American Statistical Association, 62(319), 857-861, doi:10.1080/01621459.1967.10500898.

Anderson, T. W., \& Burstein, H. (1968). Approximating the Lower Binomial Confidence Limit. Journal of the American Statistical Association, 63(324), 1413-1415, doi:10.1080/01621459.1968.10480937.

Arief, S. (1982). Regional disparities in Malaysia. Social Indicators Research, 11(3), 259-267, doi:10.1007/bf00351837.

Bakker, K. (2007). The "Commons" versus the "Commodity": Alter-globalization, antiprivatization and the human right to water in the global south. Antipode, 39(3), 430-455.

Bakker, K. (2008). The Ambiguity of Community: Debating Alternatives to Private-Sector Provision of Urban Water Supply. Water alternatives, 1(2).

Bennett, S., Woods, T., Liyanage, W. M., \& Smith, D. L. (1991). A simplified general method for cluster-sample surveys of health in developing countries. World Health Stat Q, 44(3), 98106.

Bolt, E., Schouten, T., \& Moriarty, P. From systems to service: scalling up community management. In 27th WEDC Conference, Lusaka, Zambia, 2001

Burstein, H. (1975). Finite Population Correction for Binomial Confidence Limits. Journal of the American Statistical Association, 70(349), 67-69.

Butterworth, J., Sutton, S., \& Mekonta, L. (2013). Self-Supply as a Complementary Water Services Delivery Model in Ethiopia. Water alternatives, 6(3), 405-423.

Camfield, L., Crabtree, A., \& Roelen, K. (2013). Editorial: Poverty, Vulnerability and Resilience in a Post-2015 World. Social Indicators Research, 113(2), 599-608, doi:10.1007/s11205-0130291-1.

Cleaver, F. (2005). The inequality of social capital and the reproduction of chronic poverty. World Development (Vol. 33, pp. 893-906).

Cochran, W. G. (1973, third edition). Sampling techniques. New York: John Wiley \& Sons.

CODA (2011). Informe sobre el Derecho Humano de acceso al agua potable y saneamiento en Nicaragua [Report about Human Right to Water and Sanitation access in Nicaragua]. Managua: Coalición de Organizaciones por el Derecho al Agua. 
Cotton, A., \& Bartram, J. (2008). Sanitation: on- or off-track? Issues of monitoring sanitation and the role of the Joint Monitoring Programme. Waterlines, 27(1), 12-29.

D'sa, E. R. (1986). Social indicators and spatial disparities in Papua New Guinea. Social Indicators Research, 18(3), 285-319, doi:10.1007/bf00286622.

Drown, T. (1894). Electrical purification of water. JN Engl Water Works Assoc, 8, 183.

Flores, O., Jiménez, A., \& Pérez-Foguet, A. (2013). Monitoring access to water in rural areas based on the human right to water framework: A local level case study in Nicaragua. International Journal of Water Resources Development, 29(4), 605-621.

Flores, O., Jiménez, A., \& Pérez-Foguet, A. (2014a). Including equity-oriented mechanisms for rural water supply decision making at local level. 2014 IWA World Water Congress \& Exhibition. (21-26 Septiembre 2014). Lisbon, Portugal.

Flores, O., Jiménez, A., \& Pérez-Foguet, A. (2014b). Reporting progress on Human Right to Water and Sanitation through UN water global monitoring mechanisms. Journal of Water, Sanitation and Hygiene for Development, accepted on 22 December 2014.

Garriga, R., \& Foguet, A. (2010). Improved Method to Calculate a Water Poverty Index at Local Scale. Journal of Environmental Engineering, 136(11), 1287-1298, doi:doi:10.1061/(ASCE)EE.1943-7870.0000255.

Giné-Garriga, R., de Palencia, A. J. F., \& Pérez-Foguet, A. (2013). Water-sanitation-hygiene mapping: An improved approach for data collection at local level. Science of the Total Environment, 463-464(1), 700-711.

Giné Garriga, R., \& Pérez Foguet, A. (2013). Unravelling the Linkages Between Water, Sanitation, Hygiene and Rural Poverty: The WASH Poverty Index. Water Resources Management, 27(5), 1501-1515, doi:10.1007/s11269-012-0251-6.

Government of Nicaragua (2007). National Water Law № 620 (in Spanish). Managua, La Gaceta Diario Oficial, http://www.mem.gob.ni/media/ley\%20620\%20ley\%20general\%20de\%20aguas\%20nacion ales.pdf. Accessed 14 October 2014.

Government of Nicaragua (2010). Water and Sanitation Committees Law № 722 (in Spanish). Managua, La Gaceta Diario Oficial. http://www.asamblea.gob.ni/odm/OBJETIVO\%207/1.LEY/2010.G111.LEY\%20722.PDF. Accessed 14 October 2014.

Haq, R., \& Ali, A. (2013). Development Disparities and Peculiarities: An Empirical Investigation. Social Indicators Research, 115(2), 715-729, doi:10.1007/s11205-012-0232-4.

Hunter, P. R., Zmirou-Navier, D., \& Hartemann, P. (2009). Estimating the impact on health of poor reliability of drinking water interventions in developing countries. Science of the Total Environment, 407(8), 2621-2624.

Jacangelo, J. G., \& Trussells, R. R. International Report Water and Wastewater Disinfection: Trends. In Issues and Practices, Preprints IWA 2nd World Water Congress, Berlin, 2001

Jemmali, H., \& Sullivan, C. A. (2014). Multidimensional Analysis of Water Poverty in MENA Region: An Empirical Comparison with Physical Indicators. Social Indicators Research, 115(1), 253277, doi:10.1007/s11205-012-0218-2. 
Jiménez, A., \& Pérez-Foguet, A. (2008). Improving water access indicators in developing countries: a proposal using water point mapping methodology. Water Science \& Technology: Water Supply, 8(3), 279-287, doi:10.2166/ws.2008.072.

Jiménez, A., \& Pérez-Foguet, A. (2010). Building the role of local government authorities towards the achievement of the human right to water in rural Tanzania. Natural Resources Forum, 34(2), 93-105.

Joint Monitoring Programme (2006). Core questions on drinking-water and sanitation for household surveys, . Geneva JMP.

http://www.who.int/water_sanitation_health/monitoring/oms_brochure_core_questions final24608.pdf. Accessed 14 October 2014.

Joint Monitoring Programme (2011). Report of the first Consultation on Post-2015 Monitoring of Drinking-water and Sanitation, [organized by WHO and UNICEF, hosted by the Government of Germany in berlin, 3-5 May 2011], http://www.who.int/water_sanitation_health/publications/2011/berlin_meeting.pdf Accessed 14 October 2014.

Joint Monitoring Programme (2014a). Progress on Sanitation and Drinking-water: 2014 Update, . Geneva / New York: JMP, http://www.wssinfo.org/fileadmin/user_upload/resources/JMP_report_2014_webEng.pdf . Accessed 11 February 2015.

Joint Monitoring Programme (2014b). WASH targets and indicators post-2015: Recommendations from international consultations. Updated april 2014. Retrieved from http://www.wssinfo.org/fileadmin/user_upload/resources/post-2015-WASH-targetsfactsheet-12pp.pdf Accessed 02 January 2015.

Langford, M., Bartram, J., \& Roaf, V. (2014). Revisiting Dignity: The Human Right to Sanitation. In M. Langford, \& A. F. S. Russell (Eds.), The Right to Water: Theory, Practice and Prospects. Cambridge: Cambridge University Press.

Luh, J., Baum, R., \& Bartram, J. (2013). Equity in water and sanitation: Developing an index to measure progressive realization of the human right. International Journal of Hygiene and Environmental Health, 216(6), 662-671, doi:http://dx.doi.org/10.1016/j.ijheh.2012.12.007.

Majuru, B., Jagals, P., \& Hunter, P. R. (2012). Assessing rural small community water supply in Limpopo, South Africa: Water service benchmarks and reliability. Science of the Total Environment, 435-436(1), 479-486.

McCarthy, J. (2005). Commons as counterhegemonic projects. Capitalism Nature Socialism, 16(1), 9-24, doi:10.1080/1045575052000335348.

Mehta, L. (2001). Water, difference and power: Unpacking notions of water 'users' in Kutch, India. International Journal of Water, 1(3/4), 324-342.

Melamed, C. (2012). Putting inequality in the post-2015 picture. London: Overseas Development Institute, http://www.odi.org/sites/odi.org.uk/files/odi-assets/publications-opinionfiles/7599.pdf. Accessed 14 October 2014.

Mirosa, O., \& Harris, L. M. (2011). Human Right to Water: Contemporary Challenges and Contours of a Global Debate. Antipode, 44(3), 932-949, doi:10.1111/j.1467-8330.2011.00929.x. 
Munda, G., \& Nardo, M. (2005). Non-Compensatory Composite Indicators for Ranking Countries: A Defensible Setting (I. f. t. P. a. S. o. t. Citizen, Trans.). Ispra: Joint Research Centre European Commission.

Nardo, M., Saisana, M., Saltelli, A., Tarantola, S., Hoffman, A., \& Giovannini, E. (2005). Handbook on Constructing Composite Indicators: Methodology and User Guide (O. S. Directorate, Trans.). OECD Statistics Working Paper. Paris: OECD.

Novo, P., \& Garrido, A. (2014). From policy design to implementation: an institutional analysis of the new Nicaraguan Water Law. Water Policy, doi:10.2166/wp.2014.188.

Ohlan, R. (2013). Pattern of Regional Disparities in Socio-economic Development in India: District Level Analysis. Social Indicators Research, 114(3), 841-873, doi:10.1007/s11205-012-01768.

Parmar, P. (2008). Revisiting the Human Right to Water. Australian Feminist Law Journal, 28, 7796.

Pérez-Foguet, A., \& Giné, R. (2011). Analyzing Water Poverty in Basins. Water Resources Management, 25(14), 3595-3612, doi:10.1007/s11269-011-9872-4.

Reiczigel, J. (2003). Confidence intervals for the binomial parameter: some new considerations. Statistics in Medicine, 22(4), 611-621, doi:10.1002/sim.1320.

Rob ES Bain, Stephen W Gundry, Jim A Wright, Hong Yang, Steve Pedley, \& Bartram, J. K. (2012). Accounting for water quality in monitoring access to safe drinking water as part of the Millennium Development Goals: lessons from five countries. Bulletin of the World Health Organization, 90:228-235A, doi:10.2471/BLT.11.094284.

Saisana, M., Saltelli, A., \& Tarantola, S. (2005). Uncertainty and sensitivity analysis techniques as tools for the quality assessment of composite indicators. Journal of the Royal Statistical Society: Series A (Statistics in Society), 168(2), 307-323, doi:10.1111/j.1467985X.2005.00350.x.

Saisana, M., Tarantola, S., Institute for the, P., Security of the Citizen, T., \& Economic Risk Management, U. (2002). State-of-the-art Report on Current Methodologies and Practices for Composite Indicator Development: European Commission, Joint Research Centre, Institute for the Protection and the Security of the Citizen, Technological and Economic Risk Management Unit.

Smits, S., \& Sutton, S. (2012). Self supply: The case for leveraging greater household investment in water supply. IRC International Water and Sanitation Centre, The Netherlands. http://www.waterservicesthatlast.org/resources/building_blocks/alternative_service_pro vider_options/self_supply Accessed 14 October 2014

Sutton, S., Butterworth, J., \& Mekonta, L. (2012). A hidden resource: household-led rural water supply in Ethiopia. IRC International Water and Sanitation Centre, The Netherlands. http://www.ircwash.org/sites/default/files/a_hidden_resource_web_version_aug_2013.p df Accessed 14 October 2014

UN Special Rapporteur on the human right to safe drinking water and sanitation (2014). Monitoring compliance with the human rights to water and sanitation (chapter 5). In Realising the human rights to water and sanitation: A Handbook by the UN Special Rapporteur Catarina de Albuquerque. 
United Nations (2002). The Right to Water. E/C.12/2002/1. General Comment No. 15 of the Economic and Social Council,. New York: UN.

United Nations (2010a). Report of the independent expert on the issue of human rights obligations related to access to safe drinking water and sanitation, Catarina de Alburquerque. A/HRC/15/31. New York: UN.

United Nations (2010b). Statement on the Human Right to Sanitation. Committee on Economic Social and Cultural Rights. E/C.12/45/CRP.1. .

United Nations (2010a). Declaration on the right to water. A/RES/64/292. General Assembly, New York: UN. http://www.un.org/en/ga/64/resolutions.shtml Accessed 14 October 2014.

United Nations (2010b). Human rights and access to safe drinking water and sanitation.

A/HRC/RES/15/9. New York: UN. http://daccess-ddsny.un.org/doc/UNDOC/GEN/G10/166/33/PDF/G1016633.pdf?OpenElement Accessed 14 October 2014.

United Nations (2011). Report of the Special Rapporteur on the human right to safe drinking water and sanitation, Catarina de Albuquerque. A/HRC/18/33. Human Rights Council. New York: UN.

United Nations (2012). Report of the independent expert on the issue of human rights obligations related to access to safe drinking water and sanitation, Catarina de Alburquerque. A/67/270. New York: UN. http://daccess-ddsny.un.org/doc/UNDOC/GEN/N12/456/53/PDF/N1245653.pdf?OpenElement Accessed 11 February 2015.

United Nations Children's Fund (2006). Multiple Indicator Cluster Survey Manual 2005. UNICEF, Division of Policy and Planning. New York. http://www.childinfo.org/files/Multiple_Indicator_Cluster_Survey_Manual_2005.pdf Accessed 14 October 2014

Unterhalter, E., \& Dorward, A. (2013). New MDGs, Development Concepts, Principles and Challenges in a Post-2015 World. Social Indicators Research, 113(2), 609-625, doi:10.1007/s11205-013-0292-0.

World Health Organization and UNICEF (2010). Rapid Assessment of drinking-water quality in the Republic of Nicaragua. Country report of the pilot project implementation in 2004-2005. Geneva. 